\title{
Kemampuan Penalaran Matematis Ditinjau dari Kemampuan Pemecahan Masalah
}

\author{
Dinda Kurnia Putri ${ }^{*}$, Joko Sulianto², Mira Azizah ${ }^{3}$
}

123Jurusan Pendidikan Guru Sekolah Dasar, FIP, Universitas PGRI Semarang, Indonesia

\author{
ARTICLEINFO \\ Article history: \\ Received 18 May 2019 \\ Received in revised form \\ 30 June 2019 \\ Accepted 15 July 2019 \\ Available online 25 August \\ 2019 \\ Kata Kunci: \\ Pembelajaran Matematika, \\ Kemampuan Penalaran, \\ Pemecahan Masalah \\ Keywords: \\ Mathematics Learning, \\ Reasoning Ability, Problem \\ Solving
}

\begin{abstract}
A B S T R A K
Tujuan penelitian ini untuk mendeskripsikan pelaksanaan pembelajaran matematika dan mendeskripsikan klasifikasi kemampuan penalaran matematis ditinjau dari kemampuan pemecahan masalah siswa. Penelitian ini menggunakan metode penelitian kualitatif deskriptif. Teknik pengumpulan data yang dilakukan dalam penelitian ini yaitu melalui tes, observasi, wawancara, angket, dan dokumentasi. Hasil penelitian yang diperoleh dari pembelajaran matematika termasuk dalam kategori baik dengan presentase $78 \%$, sedangkan data klasifikasi penalaran matematika didapatkan presentase sebesar $70 \%$ pada aspek memahami pengertian dalam kategori tinggi, aspek berpikir logis termasuk dalam kategori tinggi dengan presentase 53,3\%, aspek memahami contoh negatif termasuk dalam kategori sangat tinggi dengan presentase $76,7 \%$, aspek berpikir sistematis dan menentukan strategi termasuk dalam kategori tinggi dengan presentase $73,3 \%$, berpikir konsisten termasuk dalam kategori tinggi dengan presentase $66,7 \%$, aspek membuat alasan termasuk dalam kategori rendah dengan presentase $33,3 \%$, aspek berpikir deduksi termasuk dalam kategori rendah dengan presentase $36,7 \%$, aspek menentukan metode termasuk dalam kategori sangat tinggi dengan presentase $80 \%$, sedangkan pada aspek menarik kesimpulan termasuk dalam kategori tinggi dengan presentase $60 \%$. Secara keseluruhan didapatkan hasil presentase sebesar $62,3 \%$ teramasuk dalam kategori tinggi.
\end{abstract}

\section{A B S T R A C T}

The purpose of this study is to describe the implementation of mathematics learning and describe the classification of mathematical reasoning abilities in terms of students' problem solving abilities. This research uses descriptive qualitative research methods. Data collection techniques used in this study are through tests, observations, interviews, questionnaires, and documentation. The results of the study obtained from mathematics learning are included in both categories with a percentage of $78 \%$, while the classification of mathematical reasoning data obtained a percentage of $70 \%$ in understanding aspects of understanding in the high category, logical thinking aspects included in the high category with a percentage of $53.3 \%$, aspects of understanding negative examples included in the category of very high with a percentage of $76.7 \%$, aspects of systematic thinking and determining strategies included in the high category with a percentage of $73.3 \%$, thinking consistently included in the high category with a percentage of $66.7 \%$, aspects of making reasons included in the category low with a percentage of $33.3 \%$, deduction thinking aspects included in the category of low with a percentage of $36.7 \%$, aspects determining the method included in the category of very high with a percentage of $80 \%$, while the aspect of drawing conclusions included in the high category with a percentage of $60 \%$. Overall the percentage of results obtained by $62.3 \%$ included in the high category.

\footnotetext{
${ }^{1}$ Corresponding author.

E-mail addresses: dindaaputrii97@gmail.com (Dinda Kurnia Putri)
} 


\section{Pendahuluan}

Pendidikan merupakan salah satu proses dimana dapat merubah pola pikir melalui pengajaran dan pelatihan untuk menambah wawasan agar siswa lebih aktif untuk mengembangkan pola pikirnya. Mata pelajaran matematika merupakan salah satu pelajaran yang dapat mengembangkan pola pikir siswa. Matematika adalah suatu ilmu pengetahuan yang tergolong ilmu dasar serta mempunyai peranan penting dalam perkembangan ilmu pengetahuan dan teknologi (Astut, 2017). Menurut Munirah (2015) sistem pendidikan di Indonesia dewasa ini tampak ada kesenjangan antara kenginan dan realita. Secara makro dapat dilihat dalam aspek pengelolaan, peran pemerintah dan masyarakat, kurikulum atau materi ajar, pendekatan dan metodologi pembelajaran, sumber daya manusia, lingkungan kampus atau sekolah, dana, dan akreditasi. Kesenjangan dalam sistem pendidikan tersebut disebabkan karena faktor politik, ekonomi, sosial-budaya dan sebagainya yang selalu berubah sesuai dengan perubahan dan perkembangan zaman.

Matematika merupakan ilmu dasar yang memiliki peran penting dalam perkembangan kehidupan manusia. Menurut Wanti (2017) Matematika merupakan proses bernalar, pembentukan karakter dan pola pikir, pembentukan sikap objektif, jujur, sistematis, kritis dan kreatif serta sebagai ilmu penunjang dalam pengambilan suatu kesimpulan. Begitu banyak dan beragam profesi yang bisa dipilih sebagai bidang profesi berlandaskan pengetahuan dan keterampilan matematika. Misalnya: guru, ekonom, insinyur, ahli statistik, peneliti, dokter, apoteker, dan lain-lain. Hal ini sesuai dengan pendapat Susanto (2013:185) matematika merupakan salah satu disiplin ilmu yang dapat meningkatkan kemampuan berpikir dan beragumentasi, memberikan kontribusi dalm penyelesaian masalah sehari-hari dan dalam dunia kerja, serta memberikan dukungan dalam dunia kerja, serta memberikan dukungan dalam pengembangan ilmu pengetahuan dan teknologi. BSNP (2006) menyatakan bahwa mata pelajaran matematika perlu diberikan kepada semua siswa mulai sekolah dasar untuk membekali siswa dengan kemampuan berfikir logis, analitis, sistematis, kritis, dan kreatif serta kemampuan bekerja sama. Matematika terbentuk sebagai hasil pemikiran manusia yang berhubungan dengan ide, proses dan penalaran (Ruseffendi ET dalam Suherman dkk, 2001: 18). Pembelajaran matematika di sekolah dasar bertujuan untuk memberi bekal siswa tidak hanya memiliki kemampuan dalam berhitung saja tetapi juga dapat membentuk pola pikir dalam suatu pemahaman yang berhubungan dengan penalaran.

Pembelajaran matematika di sekolah menurut NCTM (2000) mempunyai enam prinsip dasar yaitu prinsip ekuitas, prinsip kurikulum, prinsip pengajaran, prinsip belajar, prinsip penilaian, dan prinsip teknologi. Pembelajaran mtematika mencakup lima kemampuan dasar matematis yang merupakan lima standar proses menurut NCTM (2000) yaitu pemecahan masalah (Problem Solving), penalaran (reasoning), komunikasi (communication), koneksi (connection) dan representasi (representation).

Hasil Programme for International Student Asseseement (PISA) tahun 2015 dalam Sulianto, dkk (2018: 1), menunjukkan adanya peningkatan kemampuan siswa Indonesia. Dibandingkan dengan hasil PISA tahun 2012. Kemampuan membaca siswa Indonesia telah meningkat dari 337 menjadi 350, kemampuan matematika meningkat dari 318 menjadi 335, dan kemampuan sains meningkat pesat dari 327 poin pada tahun 2012, menjadi 359 di tahun 2015. Peningkatan ini menunjukkan adanya pertinggian kualitas pembelajaran di Indonesia, namun kemampuan siswa Indonesia masih berada di bawah rata-rata dibandingkan 72 negara lainnya. National Center for Educational Statistics, mempulikasikan kemampuan siswa Indonesia mengacu pada hasil PISA tahun 2012 bahwa hampir semua siswa Indonesia hanya menguasai materi pelajaran sampai level 4 saja, sementara negara lain telah banyak yang mencapai level 5 dan 6. Organization for Economic Cooperation and Development (2016) memaparkan bahwa pada tahun 2015 menunjukkan bahwa kemampuan berpikir pada level 5 dan 6 siswa Indonesia hanya 0,8\% dari 8\% partisipan. Sebaliknya, dari 20\% partisipan yang berada level 2. Artinya, kemampuan berpikir siswa Indonesia masih didominasi pada low order thingking (LOT).

Nilai matematika yang rendah dalam hasil survei PISA menunjukkan bahwa tujuan mata pelajaran matematika belum sepenuhnya tercapai. Rendahnya nilai matematika tersebut berhubungan dengan kemampuan penalaran siswa, karena salah satu tujuan dari mata pelajaran matematika yang dinyatakan oleh Depdiknas 2006 dalam Susanto (2013: 190) yaitu siswa dapat menggunakan penalaran pada pola, sifat, melakukan manipulasi matematika dalam membuat generalisasi, menyusun bukti, atau menjelaskan gagasan dan pernyataan matematika.

Ball, Lewis \& Thamel (dalam Suprihatin, dkk., 2018: 9) menyatakan, "mathematical reasoning is the foundation for the construction of mathematical knowledge". Hal ini berarti kemampuan penalaran matematis adalah fondasi untuk mendapatkan pengetahuan matematika. Kemampuan penalaran sangat berhubungan dengan pola berfikir logis, analitis, dan kritis. Melalui penalaran yang baik, seseorang akan dapat mengambil kesimpulan atau keputusan yang berhubungan dengan kehidupannya sehari-hari. Hal ini sesuai dengan pendapat Sulianto (2011: 456) menyatakan penalaran merupakan suatu kegiatan, suatu proses atau aktivitas berpikir untuk menarik kesimpulan atau membuat suatu pernyataan yang 
kebenarannya telah dibuktikan atau diasumsikan sebelumnya. Seseorang dengan kemampuan penalaran yang rendah akan selalu mengalami kesulitan dalam menghadapi berbagai persoalan, karena ketidakmampuan menghubungkan fakta-fakta untuk sampai pada suatu kesimpulan. Oleh karena itu, sudah seharusnya penalaran perlu dikembangkan pada setiap individu. Secara garis besar penalaran terbagi menjadi dua, yaitu penalaran deduktif dan penalaran induktif (Sumartini, 2015: 4). Penalaran deduktif merupakan penarikan kesimpulan dari hal yang umum menuju hal yang khusus berdasarkan fakta-fakta yang ada. Sedangkan penalaran induktif merupakan suatu proses berpikir dengan mengambil keputusan yang bersifat umum atau membuat suatu pernyataan baru dari kasus-kasus yang khusus.

Berdasarkan hasil wawancara dengan guru kelas IV di SDN Sendangmulyo 01 Seamarang yaitu Bapak Prima Martha Miarzha, S.Pd.Sd. di peroleh data bahwa kemampuan penalaran matematis siswa dalam menyelesaikan soal berbasis pemecahan masalah di sekolah tersebut masih tergolong rendah. Hal itu dikarenakan siswa masih belum terbiasa mengerjakan soal berbasis pemecahan masalah dengan logika dan penalaran masing-masing. Soal yang dikerjakan siswa dari penyelesaiannya tidak berbeda jauh dengan apa yang dicontohkan oleh guru di depan kelas. Hal ini membuat pengetahuan yang dimiliki oleh siswa hanya terbatas dengan apa yang diajarkan oleh guru saja. Oleh karena itu, kemampuan penalaran yang seharusnya berkembang dalam diri siswa menjadi tidak berkembang secara optimal.

Salah satu solusi untuk mengatasi masalah siswa di SD tersebut yaitu diperlukan adanya peningkatan kemampuan penalaran yang ditinjau dari pemecahan masalah, yang dapat ditemukan dalam pembelajaran matematika, dan siswa akan dihadapkan dengan pemecahan masalah. Menurut Susanto (2013: 195) pemecahan masalah (problem solving) merupakan proses menerapkan pengetahuan (knowledge) yang telah diperoleh sebelumnya ke dalam situasi yang baru. Kemampuan pemecahan masalah merupakan kecakapan atau potensi yang dimiliki siswa dalam menyelesaikan permasalahan dan mengaplikasikan dalam kehidupan sehari-hari (Polya dalam Gunantara, dkk: 2014: 4). Salah satu solusi dari permasalahan tersebut dengan menggunakan langkah-langkah pemecahan masalah menurut Polya (1973) dalam bukunya "How To Solve It" yaitu understanding the problem (memahami masalah), devising a plan (menyusun rencana penyelesaian), carrying out the plan (melaksanakan rencana penyelesaian), dan looking back (memeriksa kembali solusi yang diperoleh). Azizah (2018: 61) menyatakan dalam pelaksanaan pembelajaran matematika tidak cukup hanya memberikan informasi berupa teori atau konsep yang bersifat hafalan saja, tetapi perlu juga berorientasi pada pengembangan keterampilanketerampilan yang dibutuhkan dalam pemecahan masalah.

Menurut Tukaryanto (2018) Pentingnya kemampuan penalaran matematik sangatlah bepengaruh dengan proses pembelajaran matematika yang mereka ikuti. Karena siswa yang mempunyai kemampuan penalaran yang baik akan mudah memahami materi matematika dan sebaliknya siswa yang kemampuan penalaran matematikanya rendah akan sulit memahami materi matematika. Kemampuan penalaran matematis merupakan kemampuan yang sangat penting dan harus dimiliki siswa dalam memecahkan masalah matematika (Hidayati dan Widodo, 2015: 132). Hal tersebut dikarenakan bahwa setiap permasalahan matematika harus diselesaikan dengan proses bernalar, dan bernalar dapat dipahami serta dilatih dengan memecahkan masalah matematika. Guru dapat mengkaji kemampuan penalaran siswa dengan mengamati cara siswa memecahkan masalah matematika. Melalui jawaban siswa yang bervariasi guru dapat membedakan atau mengklasifikasi jawaban siswa, sehingga diperoleh gambaran sejauh mana kemampuan penalaran siswa dalam memecahkan masalah matematika. Untuk mengukur kemampuan penalaran matematis siswa diberikan soal yang berpedoman pada aspek penalaran yaitu asek memahami pengertian, berpikir logis, memahami contoh negatif, berpikir sistematis, berpikir konsisten, membuat alasan, menentukan strategi, berpikir deduksi, menentukan metode serta menarik kesimpulan (Sulianto, 2011: 454). Menurut Setiadi (2012) menyatakan bahwa penalaran dapat secara langsung meningkatkan hasil belajar peserta didik, yaitu jika peserta didik diberi kesempatan untuk menggunakan keterampilan bernalarnya dalam melakukan pendugaan-pendugaan berdasarkan pengalaman sendiri, sehingga peserta didik akan lebih mudah memahami konsep. Menurut Agustin (2016) Penalaran matematika tidak hanya penting untuk melakukan pembuktian atau pemeriksaan program, tetapi juga untuk inferensi dalam suatu sistem kecerdasan buatan. Pada dasarnya setiap penyelesaian soal matematika memerlukan kemampuan penalaran. Melalui penalaran, mahasiswa diharapkan dapat melihat bahwa matematika merupakan kajian yang masuk akal atau logis. Dengan demikian mahasiswa merasa yakin bahwa matematika dapat dipahami, dipikirkan, dibuktikan, dan dapat dievaluasi. Berdasarkan uraian yang telah dijelaskan sebelumnya, maka dapat disimpulkan bahwa kemampuan penalaran matematika mahasiswa adalah kemampuan atau kesanggupan mahasiswa dalam menyelesaikan soal yang diberikan. Sulistiawati (2014), rendahnya kemampuan penalaran matematis siswa, salah satunya disebabkan oleh pembelajaran matematika yang kurang melibatkan siswa. Apabila dilihat dari kenyataan dilapangan, metode mengajar yang digunakan oleh guru secara umum cenderung guru yang lebih aktif dan siswa pasif menerima 
informasi yang disampaikan oleh guru. Penelitian ini bertujuan untuk: menelaah kualitas kemampuan penalaran matematis siwa pada materi segitiga dan segiempat.

Seperti halnya sama dengan penelitian yang dilakukan oleh Sumartini (2015) yang menyimpulkan bahwa kemampuan penalaran matematis siswa mengalami peningkatan setelah mendapatkan pembelajaran berbasis masalah karena lebih sering memecahkan masalah matematika dibandingkan dengan siswa yang mendapatkan pembelajaran secara konvensional. Kemudian berdasarkan penelitian yang dilakukan oleh Hadi dan Radiyatul (2014) menyimpulkan bahwa pemecahan masalah merupakan bagian dari pembelajaran matematika yang sangat penting karena dalam proses pembelajaran atau penyelesaiannya siswa dapat memperoleh pengalaman menggunakan pengetahuan yang sudah dimiliki. Salah satunya yaitu siswa dapat menggunakan metode pemecahan masalah menurut Polya. Hal ini dapat dilihat dari hasil penelitian yang menunjukkan bahwa kemampuan pemecahan masalah siswa lebih tinggi pada setiap pertemuan dan hasil belajar siswa yang menggunakan metode pemecahan masalah menurut Polya berada pada kualifikasi sangat baik.

Beradasarkan uraian di atas, peneliti melakukan penelitian dengan judul "Kemampuan Penalaran Matematis Ditinjau dari Kemampuan Pemecahan Masalah Siswa Kelas IV SDN Sendangmulyo 01 Semarang". Penelitian ini dilakukan karena peneliti tertarik untuk mengetahui tentang kemampuan penalaran matematis yang ditinjau dari kemampuan pemecahan masalah siswa di sekolah dasar.

\section{Metode}

Metode yang digunakan dalam penelitian ini adalah metode kualitatif dengan menggunakan pendekatan deskriptif kualitatif. Lokasi dalam penelitian di SDN Sendangmulyo 01 Semarang. Pengumpulan data dilakukan melalui observasi, wawancara, angket, dokumentasi dan untuk pengumpulan data kemampuan penalaran matematis siswa menggunakan soal tes. Keabsahan data dilakukan dengan cara triangulasi teknik.

\section{Hasil dan Pembahasan}

Data hasil penelitian pada pelaksanaan pembelajaran matematika diperoleh dari angket yang diberikan pada dua responden yaitu guru kelas IV ditampilkan pada Tabel 1 berikut:

Tabel 1. Data Hasil Penelitian Pelaksanaan Pembelajaran Matematika

\begin{tabular}{clcc}
\hline No & \multicolumn{1}{c}{ Aspek } & Presentase & Katagori \\
\hline 1 & Aspek Pembelajaran & $78 \%$ & Baik \\
2 & Aspek Pendekatan Saintifik & $80 \%$ & Baik \\
3 & Aspek Penalaran Siswa & $77 \%$ & Baik \\
\hline
\end{tabular}

Berdasarkan data pada Tabel 1 hasil dari pemerolehan penilaian skor pada aspek pembelajaran diperoleh hasil presentase sebesar 78\% termasuk dalam kategori baik, aspek pendekatan saintifik diperoleh hasil presentase sebesar $80 \%$ dalam kategori baik, sedangkan pada aspek penalaran siswa diperoleh hasil presentase sebesar $77 \%$ dalam kategori baik. Secara keseluruhan hasil temuan dari data angket yang diperoleh yaitu sebesar 78\% termasuk dalam kategori baik.

Data hasil penelitian dilihat dari kemampuan penalaran siswa dapat diperoleh dari uji tes yang dilakukan pada kelas IV ditampilkan pada Tabel 2 berikut:

Tabel 2. Data Hasil Penelitian Kemampuan Penalaran Matematis Siswa Kelas IV

\begin{tabular}{clcc}
\hline No & \multicolumn{1}{c}{ Aspek Penalaran } & $\begin{array}{c}\text { Presentase Jawaban } \\
\text { Benar }\end{array}$ & Kategori \\
\hline 1 & Memahami pengertian & $70 \%$ & Tinggi \\
2 & Berpikir logis & $53,3 \%$ & Tinggi \\
3 & Memahami contoh negatif & $76,7 \%$ & Sangat Tinggi \\
4 & Berpikir sistematis & $73,3 \%$ & Tinggi \\
5 & Berpikir konsisten & $66,7 \%$ & Tinggi \\
6 & Membuat alasan & $33,3 \%$ & Rendah \\
7 & Menentukan strategi & $73,3 \%$ & Tinggi \\
8 & Berpikir deduksi & $36,7 \%$ & Rendah \\
\hline
\end{tabular}




\begin{tabular}{cccc}
\hline 9 & Menentukan metode & $80 \%$ & Sangat Tinggi \\
10 & Menarik kesimpulan & $60 \%$ & Tinggi \\
\hline
\end{tabular}

Berdasarkan data pada Tabel 2 data hasil penelitian aspek penalaran matematis didapatkan hasil presentase sebesar 70\% pada aspek memahami pengertian dalam kategori tinggi, pada aspek berpikir logis termasuk dalam kategori tinggi dengan hasil presentase sebesar 53,3\%, aspek memahami contoh negatif mendapatkan hasil presentase sebesar 76,7\% dengan kategori sangat tinggi, aspek berpikir sistematis dan menentukan strategi termasuk dalam kategori tinggi dengan mendapatkan hasil presentase yang sama yaitu 73,3\%, aspek berpikir konsisten termasuk dalam kategori tinggi dengan hasil presentase sebesar 66,7\%, aspek membuat alasan mendapatkan hasil presentase sebesar 33,3\% termasuk dalam kategori rendah, aspek berpikir deduksi termasuk dalam kategori rendah dengan presentase yang diperoleh sebesar 36,7\%, aspek menentukan metode termasuk dalam kategori tinggi dengan hasil presentase sebesar $80 \%$, serta pada aspek yang terakhir yaitu aspek menarik kesimpulan termasuk dalam kategori tinggi dengan presentase sebesar $60 \%$. Secara keseluruhan didapatkan hasil presentase sebesar $62,3 \%$. Artinya dalam kemampuan penalaran matematis ditinjau dari kemampuan pemecahan masalah siswa kelas IV di SDN Sendangmulyo 01 Semarang sudah termasuk dalam kategori tinggi.

Dilihat dari hasil presentase pada tabel 2 dari masing-masing soal mengalami naik turun presentase pada masing-masing butir soal dengan total soal keseluruhan sebanyak 10 butir soal. Dari beberapa soal didapatkan hasil presentase yang sama yaitu sebesar 73,3\% ditunjukkan pada butir soal nomor empat yaitu aspek penalaran berpikir sistematis dan butir soal nomor tujuh yaitu aspek penalaran menentukan strategi termasuk dalam kategori tinggi. Secara keseluruhan didapatkan hasil presentase terendah yaitu sebesar 33,3\% ditunjukkan pada butir soal nomor enam yaitu aspek penalaran membuat alasan dan hasil peresentase tertinggi sebesar $80 \%$ ditunjukkan pada butir soal nomor sembilan yaitu aspek penalaran menentukan metode.

Perbedaan hasil presentase pada masing-masing butir soal bisa diakibatkan oleh faktor tingkatan soal pada setiap aspek penalaran dan kurangnya pemahaman siswa terhadap butir soal. Sehingga siswa merasa kesulitan dalam mengerjakan, menentukan strategi, menentukan rumus untuk memecahkan masalah dari persoalan yang ada. Faktor yang disebabkan dari pemerolehan hasil siswa di atas, hal tersebut juga sama dengan pendapat Wasliman dalam Susanto (2013: 12) yaitu hasil belajar yang dicapai peserta didik merupakan hasil interaksi antara berbagai faktor yang mempengaruhi, baik faktor internal maupun eksternal. Faktor yang dapat mempengaruhi hasil peserta didik termasuk dalam faktor internal dimana faktor internal merupakan faktor yang bersumber dari dalam diri peserta didik yang dapat mempengaruhi kemampuan belajarnya. Adanya pemerolehan hasil presentase dengan nilai yang diperoleh, itu bearti siswa dapat memahami bentuk dan maksud soal serta bagaimana cara siswa untuk memecahkan masalah pada soal dengan kemampuan penalaran yang dimiliki siswa.

Hasil tes penalaran matematis siswa yang diperoleh menunjukkan bahwa naik turunnya hasil presentase, secara keseluruhan kemampuan penalaran sudah termasuk dalam kategori tinggi dengan presentase di atas 50\% yaitu 62,3\%. Artinya kemampuan penalaran siswa kelas IV di SDN Sendangmulyo 01 Semarang sudah maksimal.

\section{Simpulan dan Saran}

Berdasarkan hasil penelitian dan hasil pembahasan yang telah diuraikan, maka dapat disimpulkan bahwa: 1) Hasil analisis terkait pelaksanaan pembelajaran matematika di SDN Sendangmulyo 01 Semarang sudah terlaksana dengan baik. Pada pelaksanaanya antara guru dan siswa tercipta interaksi yang baik meskipun pada kegiatan pembelajaran guru tidak menggunakan media pembelajaran. Pada proses pengamatan, guru menyampaikan materi dengan bahasa lisan yang mudah dipahami siswa. Selain itu, dilihat dari aspek pembelajaran didapatkan hasil presentase sebesar 78\%, aspek pendekatan saintifik didapatkan hasil presentase sebesar $80 \%$ serta pada aspek penalaran siswa didapatkan hasil presentase sebesar 77\%. Secara keseluruhan hasil temuan dari ketiga aspek tersebut didapatkan hasil presentase sebesar 78\%. Presentase dari keseluruhan hasil tersebut termasuk dalam kategori baik. 2) Kemampuan penalaran matematis siswa kelas IV SDN Sendangmulyo 01 Semarang ditinjau dari aspek penalaran serta pemecahan masalah dengan materi segi banyak dan bangun datar terdapat dalam 10 soal penalaran dari 10 aspek penalaran matematis. Jika didapatkan hasil presentase di bawah $50 \%$ artinya penalaran matematis siswa dikategorikan masih rendah. Secara keseluruhan didapatkan hasil presentase sebesar $62,3 \%$. Artinya kemampuan penalaran matematis ditinjau dari kemampuan pemecahan masalah siswa kelas IV di SDN Sendangmulyo 01 Semarang sudah termasuk dalam kategori tinggi.

Berdasarkan hasil penelitian dan hasil pembahasan yang telah diuraikan, maka saran yang dapat diberikan adalah sebagai berikut: 1) Bagi siswa, dalam proses pembelajaran sebaiknya siswa 
mengikuti proses belajar dengan baik agar dapat memahami materi yang disampaikan oleh guru sehingga dalam mengerjakan soal ketika ulangan siswa bisa mengerjakan soal tanpa menemui kesulitan dan bila merasa ada soal yang sulit dipahami sebaiknya ditanyakan kepada guru kelas. 2) Bagi guru, kemampuan penalaran matematis dalam pemecahan masalah matematika siswa kelas IV sebaiknya diajarkan secara berkelanjutan, karena kemampuan penalaran matematis dapat terus berkembang seiring dengan banyaknya latihan soal pemecahan masalah yang dikerjakan. Maka diperlukan peran guru untuk membantu dan membiasankan siswa dalam mempelajari dan mengerjakan latihan soal yang dapat mengembangkan kemampuan penalaran matematis siswa dalam pemecahan masalah. 3) Bagi peneliti, berikutnya diharapkan dapat berinovasi dengan mengembangkan model penelitian, mengembangkan instrumen serta perangkan lainnya yang lebih menarik serta dapat mendukung dalam peningkatan kemampuan penalaran matematis yang dimiliki siswa.

\section{Daftar Rujukan}

Agustin, Ririn Dwi.2016. Kemampuan Penalaran Matematika Mahasiswa Melalui Pendekatan Problem Solving. Volume. 5, No. 2, Hal. 179-188. Tersedia Pada: http://www.ojs.umsida.ac.id/.

Astuti, Erni Puji. 2017. Penalaran Matematis Dalam Menyelesaikan Masalah Matematika Siswa SMP. Jurnal Pendidikan Surya Edukasi (JPSE), Volume: 3, Nomor: 2, Hal. 83-91. Tersedia Pada: http://ejournal.umpwr.ac.id/index.php/surya/article/download/4341/4040.

Azizah, Mira. Joko Sulianto dan Nyai Cintang. 2018. Analisis Keterampilan Berpikir Kritis Siswa Sekolah Dasar Pada Pembelajaran Matematika Kurikulum 2013. Jurnal Penelitian Pendidikan. Vol.35. Nomor 1.

BSNP. 2006. Panduan Penyusunan Kurikulum Tingkat Satuan Pendidikan Jenjang Pendidikan Dasar dan Menengah. Badan Standar Nasional Pendidikan. Jakarta.

Gunantara, Md Suarjana dan Pt. Nanci Riastini. 2014. Penerapan Model Pembelajaran Problem Based Learning Untuk Meningkatkan Kemampuan Pemecahan Masalah Matematika Siswa Kelas V. Jurnal Mimbar PGSD Universitas Pendidikan Ganesha. Vol. 2. No. 1.

Hidayati, Anisatul dan Suryo Widodo. 2015. Proses Penalaran Matematis siswa dalam Memecahkan Masalah Matematika pada Materi Pokok Dimensi Tiga Berdasarkan Kemampuan Siswa di SMA Negeri 5 Kediri. Jurnal Math Educator Nusantara. Volume 01. No. 02.

Munirah. 2015. Sistem Pendidikan di Indonesia: antara keinginan dan realita. Auladuna, Vol. 2 No. 2 Hal. 233-245. Tersedia Pada: http://journal.uin-alauddin.ac.id/index.php/auladuna/article/view/879.

NCTM. 2000. Principles and Standards for School Mathematics. The National Council of Teachers of Mathematics. Virginia.

Polya, G. 1973. How To Solve It. A New Aspect of Mathematical Method. Princeton University Pres, Princeton, New Jersey.

Setiadi, dkk. (2012). Kemampuan Matematika Siswa SMP Indonesia Menurut Benchmark Internasional TIMSS 2011. Jakarta: Kemdikbud.

Suherman, Erman, dkk. 2001. Strategi Pembelajaran Matematika Kontemporer. Bandung: JICA- Universitas Pendidikan Indonesia (UPI).

Sulianto, Joko. 2011. Keefektifan Model Pembelajaran Kontekstual dengan Pendekatan Open Ended dalam Pemecahan Masalah. Jurnal Ilmu Pendidikan. Jilid 17. No. 6.

Sulianto, Joko, Nyai Cintang dan Mira Azizah. 2018. Higher Order Thinking Skills (HOTS) Siswa Pada Mata Pelajaran Matematika di Sekolah Dasar Pilot Project Kurikulum 2013 di Kota Semarang. Semarang: LPPM Universitas PGRI Semarang. 
Sulistiawati. (2014). “Analisis Kesulitan Belajar Kemampuan Penalaran Matematis Siswa pada Materi Luas Permukaan dan Volume Limas". Proceeding Seminar Nasioanal Pendidikan Matematika, Sains, dan TIK STKIP Surya 2014.

Sumartini, Tina Sri. 2015. Peningkatan Kemampuan Penalaran Matematis Siswa Melalui Pembelajaran Berbasis Masalah. Jurnal Pendidikan Matematika. Vol. 5 No. 1.

Suprihatin, Tri Roro. Rippi Maya dan Eka Senjayawati. 2018. Analisis Kemampuan Penalaran Matematis Siswa SMP pada Materi Segitiga dan Segiempat. Jurnal Kajian Pembelajaran Matematika. Volume 2. No. 1.

Susanto, Ahmad. 2013. Teori Belajara dan Pembelajaran di Sekolah Dasar. Jakarta: Prenadamedia Group.

Tukaryanto, Putriaji Hendikawati, Sugeng Nugroho. 2018. Peningkatan Kemampuan Penalaran Matematik dan Percaya Diri Siswa Kelas X Melalui Model Discovery Learning. PRISMA, Prosiding Seminar Nasional Matematika. Tersedia Pada: https://journal.unnes.ac.id/sju/index.php/prisma/.

Wanti, Nopia, Juariah, Ehda Farlina, Hamdan Sugilar, Rahayu Kariadinata. 2017. Pembelajaran Induktif Pada Kemampuan Penalaran Matematis dan Self-Regulated Learning Siswa. Jurnal Analisa Vol. 3 No. 1 Hal. 56-69. Tersedia Pada: http://journal.uinsgd.ac.id/index.php/analisa/index. 